\title{
Determination of Inorganic Species of Sb and Te in Cereals by Hydride Generation Atomic Fluorescence Spectrometry
}

\author{
Mariela N. M. Reyes, Maria L. Cervera* and Miguel de la Guardia \\ Department of Analytical Chemistry, University of Valencia, 50 Dr. Moliner Street, \\ 46100 Burjassot, Valencia, Spain
}

\begin{abstract}
Neste trabalho foi desenvolvido um sistema não cromatográfico rápido, sensível e simples para a determinação de $\mathrm{Sb}$ (III), $\mathrm{Sb}(\mathrm{V}), \mathrm{Te}(\mathrm{IV})$ e $\mathrm{Te}(\mathrm{VI})$ em amostras de cereais. O procedimento baseia-se na extração assistida por ultra-som e na determinação por espectrometria de fluorescência atômica acoplada com geração de hidretos (HG AFS). Foram realizados estudos preliminares com o intuito de avaliar a eficiência da extração usando $1 \mathrm{~mol} \mathrm{~L}^{-1}$ ácido fosfórico, $1 \mathrm{~mol} \mathrm{~L}^{-1}$ ácido nítrico, água regia, $1 \mathrm{~mol} \mathrm{~L}^{-1}$ ácido sulfúrico e $6 \mathrm{~mol} \mathrm{~L}^{-1}$ ácido clorídrico. A extração com água régia apresentou uma evidente interconversão das espécies durante o processo. No entanto, $\mathrm{o}_{2} \mathrm{SO}_{4}$ apresentou-se como o melhor agente de extração com eficiências maiores do que 90\% em relação ao conteúdo total de $\mathrm{Sb}$ e Te (ambos os elementos foram previamente quantificados), não apresentando interconversão nenhuma. Estudos de recuperação para diferentes níveis de adição das espécies comprovaram a não interconversão das espécies. O método forneceu limites de detecção na faixa de 0,1 a $1,0 \mathrm{ng} \mathrm{g}^{-1}$ com desvios padrão relativos de 5,4-9,2\% para 10 análises independentes de amostras que continham baixas concentrações de espécies de $\mathrm{Sb}$ e Te.
\end{abstract}

A non-chromatographic fast, sensitive and easy method has been developed for the determination of $\mathrm{Sb}(\mathrm{III}), \mathrm{Sb}(\mathrm{V}), \mathrm{Te}(\mathrm{IV})$ and $\mathrm{Te}(\mathrm{VI})$ in cereal samples. The procedure is based on ultrasound assisted extraction and determination by hydride generation atomic fluorescence spectrometry (HG AFS). Preliminary studies were made in order to get the best extraction efficiency using $1 \mathrm{~mol} \mathrm{~L}^{-1}$ phosphoric acid, $1 \mathrm{~mol} \mathrm{~L}^{-1}$ nitric acid, aqua regia, $1 \mathrm{~mol} \mathrm{~L}^{-1}$ sulfuric acid and $6 \mathrm{~mol} \mathrm{~L}^{-1}$ hydrochloric acid. The extraction with aqua regia showed a clear interconversion of the species during the process, being $\mathrm{H}_{2} \mathrm{SO}_{4}$ the best extractant with efficiencies greater than $90 \%$ from the total content of $\mathrm{Sb}$ and $\mathrm{Te}$ quantified previously and without species interconversion. This point was checked by recovery experiments at different spiked levels. The method provided limits of detection values from 0.1 to $0.5 \mathrm{ng} \mathrm{g}^{-1}$ with relative standard deviation values from 5.4 to $9.2 \%$ of 10 independent analysis of samples containing few $\mathrm{ng} \mathrm{g}^{-1}$ of $\mathrm{Sb}$ and Te species.

Keywords: antimony, tellurium, cereals, speciation, hydride generation atomic fluorescence spectrometry

\section{Introduction}

Natural concentrations of $\mathrm{Sb}$ and $\mathrm{Te}$ in the environment are low. Their abundance in the earth's crust is of the order of $0.2-0.3 \mathrm{mg} \mathrm{kg}^{-1} .{ }^{1}$ In its metallic form, the major use of $\mathrm{Sb}$ is as hardener for $\mathrm{Pb}$, e.g., in lead-acid batteries, cable sheathings, ammunition, and as a component in

*e-mail: m.luisa.cervera@uv.es semiconductors. Important anthropogenic sources of $\mathrm{Sb}$ in the environment are emissions from vehicles (where it is used as a fire-retardant in brake linings), waste disposal and incineration, fuel combustion, metal smelters, and shooting activities. ${ }^{2,3}$ Antimony has no known essential biological function. Similar to other trace elements, it can be toxic at elevated concentrations, and some $\mathrm{Sb}$ compounds are even considered potentially carcinogenic. A potentially important $\mathrm{Sb}$ exposure pathway to humans 
and animals in areas with contaminated soils is through food and feed plants. ${ }^{4}$

On the other hand, pentavalent antimonials, such as, meglumine antimoniate and sodium stibogluconate are used for the treatment of leishmaniasis caused by protozoa. ${ }^{5}$ In addition, some $\mathrm{Sb}$ compounds show antitumor activity. ${ }^{6}$

Tellurium is a non-essential toxic element widely spread in nature, usually at low concentration levels which can affect various organs. ${ }^{7}$ Some studies indicated that tellurium's toxicity, bioavailability, and environmental transport mechanism highly depend on its chemical form and oxidation state; being tellurite 10 times more toxic than tellurate. ${ }^{8}$

The Food and Nutrition Board of the U. S. National Research Council recommends for a $\mathrm{Sb}$ intake of 50-200 $\mu$ day $^{-1}, 10-40 \mu \mathrm{g}$ day ${ }^{-1}$ for infants and 20-120 $\mu$ day $^{-1}$ for children under the age of $6 .{ }^{9}$ The daily intake of tellurium for the average adult is judged to be around $0.6 \mathrm{mg}$ and it is part of our diet. ${ }^{10}$

In comparison with extensive speciation studies carried out of other elements such as As and Se, only few works have dealt with the speciation of $\mathrm{Sb}$ and Te. Table 1 shows the data reported in the literature on the speciation analysis of $\mathrm{Sb}$ and $\mathrm{Te}$ in food samples. As it can be seen, some of the analysis has been carried out on certified reference materials. Major contributions on the $\mathrm{Sb}$ and Te speciation have been given by the authors in food samples such as garlic, mushrooms and milk.
Antimony(III) has been determined in meals and certified materials by voltammetry, ${ }^{11-13}$ and by high performance liquid chromatography (HPLC) in environmental samples. ${ }^{14}$ In previous works, non-chromatographic determination of $\mathrm{Sb}(\mathrm{III})$ and $\mathrm{Sb}(\mathrm{V})$ was made in garlic, mushroom and milk samples by using hydride-generation-atomic-fluorescence spectrometry (HG AFS). ${ }^{15-17}$ The simultaneous speciation of As and Sb by (HPLC ICP MS) in fish sample was studied by Morita and co-workers. ${ }^{18}$

The methods proposed for Te speciation are complex and involve several sequential steps, thus making their use very difficult in routine analysis. In general these methods are based on chromatographic separations with element-specific detectors. A method for the determination of tellurite [Te(IV)] and tellurate [Te(VI)] by ion chromatography with inductively coupled plasma mass spectrometric detection (ICP MS) was developed by Kuo and Jiang, ${ }^{19}$ the analysis being carried out using dynamic reaction cell. A procedure for the fractionation and determination of $\mathrm{Te}(\mathrm{IV})$ and $\mathrm{Te}(\mathrm{VI})$ using a tungsten furnace was described by Narukawa. ${ }^{20}$ The speciation analysis of tellurium by ICP MS using solid-phase extraction in the presence of ammonium pyrrolidine dithiocarbamate in water samples was studied by Yu and co-workers. ${ }^{21} \mathrm{~A}$ highly sensitive non-chromatographic procedure for the speciation of Te in milk samples by HG AFS was developed by Cava Montesinos and co-workers. ${ }^{22}$ It was used aqua regia as

Table 1. Contents of $\mathrm{Sb}$ and Te inorganic species in food samples

\begin{tabular}{|c|c|c|c|c|}
\hline Specie & Sample & Technique & Concentration & Reference \\
\hline $\mathrm{Sb}(\mathrm{III})$ & $\begin{array}{c}\text { BCR-CRM } 189 \\
\text { NIST-SRM 1567a } \\
\text { NIST-SRM 1568a }\end{array}$ & Voltammetry & $\begin{array}{l}6.6 \pm 0.4 \mu \mathrm{g} \mathrm{g}^{-1} \\
6.5 \pm 0.6 \mu \mathrm{g} \mathrm{g}^{-1} \\
7.3 \pm 0.5 \mu \mathrm{g} \mathrm{g}^{-1}\end{array}$ & 11 \\
\hline $\mathrm{Sb}(\mathrm{III})$ & $\begin{array}{l}\text { BCR-CRM } 189 \\
\text { NIST-SRM } 1567 \mathrm{a}\end{array}$ & Voltammetry & $\begin{array}{l}7.2 \pm 0.4 \mu \mathrm{g} \mathrm{g}^{-1} \\
6.6 \pm 0.4 \mu \mathrm{g} \mathrm{g}^{-1}\end{array}$ & 12 \\
\hline $\mathrm{Sb}(\mathrm{III})$ & $\begin{array}{l}\text { Whole meal } \\
\text { Wheat meal } \\
\text { Maize meal }\end{array}$ & Voltammetry & $\begin{array}{c}0.94 \pm 0.06 \mu \mathrm{g} \mathrm{g}^{-1} \\
0.41 \pm 0.04 \mu \mathrm{g} \mathrm{g}^{-1} \\
0.171 \pm 0.008 \mu \mathrm{g} \mathrm{g}^{-1}\end{array}$ & 13 \\
\hline $\begin{array}{l}\mathrm{Sb}(\mathrm{III}) \\
\mathrm{Sb}(\mathrm{V})\end{array}$ & Garlic & HG AFS & $\begin{array}{l}7.2-17.1 \mathrm{ng} \mathrm{g}^{-1} \\
4.7-5.8 \mathrm{ng} \mathrm{g}^{-1}\end{array}$ & 15 \\
\hline $\begin{array}{l}\mathrm{Sb}(\mathrm{III}) \\
\mathrm{Sb}(\mathrm{V})\end{array}$ & Mushrooms & HG AFS & $\begin{array}{l}4.6-11.4 \mathrm{ng} \mathrm{g}^{-1} \\
14.7-21.2 \mathrm{ng} \mathrm{g}^{-1}\end{array}$ & 16 \\
\hline $\begin{array}{l}\mathrm{Te}(\mathrm{IV}) \\
\mathrm{Te}(\mathrm{VI})\end{array}$ & Garlic & HG AFS & $\begin{array}{l}5.4-9.4 \mathrm{ng} \mathrm{g}^{-1} \\
0.6-1.0 \mathrm{ng} \mathrm{g}^{-1}\end{array}$ & 15 \\
\hline $\begin{array}{l}\mathrm{Sb}(\mathrm{III}) \\
\mathrm{Sb}(\mathrm{V})\end{array}$ & Milk & HG AFS & $\begin{array}{l}1.3-2.4 \mathrm{ng} \mathrm{g}^{-1} \\
2.3-8.3 \mathrm{ng} \mathrm{g}^{-1}\end{array}$ & 17 \\
\hline $\mathrm{Sb}(\mathrm{III})$ & Fish & HPLC ICP MS & $0.010 \pm 0.004 \mathrm{mg} \mathrm{kg}^{-1}$ & 18 \\
\hline $\begin{array}{l}\mathrm{Te}(\mathrm{IV}) \\
\mathrm{Te}(\mathrm{VI})\end{array}$ & Milk & HG AFS & $\begin{array}{l}0.7-6.3 \mathrm{ng} \mathrm{g}^{-1} \\
0.4-4.2 \mathrm{ng} \mathrm{g}^{-1}\end{array}$ & 22 \\
\hline
\end{tabular}


extractant with and without pre-reduction with potassium bromide at $75 \pm 5{ }^{\circ} \mathrm{C}$ during $30 \mathrm{~min}$ inside a water bath.

Nowadays there is special attention in foods such as cereals, vegetables and pulses (dry bean seeds), because they are an important base of the diet around the world. On the other hand, from the methodological point of view it is clear that non-chromatographic methods of elemental speciation may offer cheaper, simpler, faster and more sensitive procedures than chromatographic ones, ${ }^{23}$ and thus, they can offer a valuable alternative for routine speciation analysis. So, the aim of this work has been the development and application of a simple analytical procedure for the quantification of inorganic species of $\mathrm{Sb}$ and Te in cereal samples by HG AFS.

\section{Experimental}

\section{Reagents, solutions and samples}

All reagents used were of analytical grade and all solutions were prepared in ultrapure water with a minimum resistivity of $18 \mathrm{M} \Omega \mathrm{cm}$ obtained from a Milli-Q Millipore system (Billerica, MA, USA). The $1000 \mathrm{mg} \mathrm{L}^{-1} \mathrm{Sb}$ (III) stock solution was from Scharlau Chemie (Barcelona, Spain) and $\mathrm{Sb}(\mathrm{V})$ stock standard was prepared by dissolving in water the adequate amount of $\mathrm{H}_{6} \mathrm{KO}_{6} \mathrm{Sb}$ from Fluka (Buchs, Switzerland). The stock solution of Te(IV) was prepared by dissolving in ultrapure water an appropriate amount of $\mathrm{Na}_{2} \mathrm{TeO}_{3}$ Sigma Aldrich (Steinheim, Germany) and Te(VI) standards were prepared by dissolving $\mathrm{H}_{6} \mathrm{O}_{6}$ Te from Fluka. For sample preparation $37 \% \mathrm{v} / \mathrm{v} \mathrm{HCl}$ from Merck and $65 \%$ v/v $\mathrm{HNO}_{3}$ from J. T. Baker (Deventer, Holland) were used. A solution of $50 \% \mathrm{~m} / \mathrm{v}$ KI Merck with $10 \% \mathrm{~m} / \mathrm{v}$ ascorbic acid from Scharlau Chemie was employed to reduce $\mathrm{Sb}(\mathrm{V})$ to $\mathrm{Sb}$ (III), while $\mathrm{KBr}$ from Scharlau Chemie was employed to reduce Te(VI) to Te(IV). The ashing agent used for dry ashing of samples before the determination of the total trace element content was a mixture of $20 \% \mathrm{~m} / \mathrm{v} \mathrm{Mg}\left(\mathrm{NO}_{3}\right) \cdot 6 \mathrm{H}_{2} \mathrm{O}$ and $2 \% \mathrm{~m} / \mathrm{v} \mathrm{MgO}$, both from Scharlau Chemie. Sodium tetrahydroborate from Fluka, dissolved in $0.1 \mathrm{~mol} \mathrm{~L}^{-1}$ $\mathrm{NaOH}$ from Scharlau Chemie was used to generate the corresponding hydrides before the AFS determination of $\mathrm{Sb}$ and $\mathrm{Te}$, this solution was prepared daily and filtered before use. For the extraction of inorganic species a $1 \mathrm{~mol} \mathrm{~L} \mathrm{H}_{2} \mathrm{SO}_{4}$ from Scharlau Chemie and $0.1 \% \mathrm{~m} / \mathrm{v}$ solution of the disodium salt of ethylenediaminotetraacetic acid from Panreac (Barcelona, Spain) were used. Argon C-45 with purity higher than $99.995 \%$ was employed as carrier gas and synthetic air was used in the Perma Pure drier system. Both gases were supplied by Carburos Metálicos (Barcelona, Spain).

\section{Instrumental}

A continuous flow HG AFS model PSA Millenium Excalibur 10055 from PS Analytical (Kent, UK) was used for the analytical determinations. Boosted discharge hollow cathode lamps for $\mathrm{Sb}$ and $\mathrm{Te}$, both from Photron (Victoria, Australia), were employed as excitation source. The instrumental parameters were adjusted according to the manufacturer recommendations, except the concentrations of $\mathrm{HCl}$ and sodium borohydride $\left(\mathrm{NaBH}_{4}\right)$, sample introduction system and the sample volume, which were implemented in previous studies. ${ }^{15,17,22}$ So, $\mathrm{HCl}$ concentration was fixed at 3.5 and $4 \mathrm{~mol} \mathrm{~L}^{-1}$ for $\mathrm{Sb}$ and Te respectively, being the $\mathrm{NaBH}_{4}$ concentration $0.7 \% \mathrm{~m} / \mathrm{v}$ for $\mathrm{Sb}$ and $0.8 \% \mathrm{~m} / \mathrm{v}$ for Te. In all experiments $\mathrm{NaBH}_{4}$ and $\mathrm{HCl}$ flow rates employed were 4.5 and $9 \mathrm{~mL} \mathrm{~min}^{-1}$ respectively. An ultrasound water bath from Branson (Danbury, CT, USA) for 10 tubes placed vertically inside it, $2.8 \mathrm{~L}$ of volume and operated at $130 \mathrm{~W}$ and $40 \mathrm{~Hz}$ was used for sample extraction. Other equipment included a sand bath Selecta (Model 600709, Abrera, Spain), and a Lenton ECF 12/45A muffle furnace equipped with a Eurotherm 2416 controller from Biometa (Lanera, Spain).

\section{Certified reference materials and samples}

Two certified reference materials were used, NIST 1573a (Tomato leaves) from the National Institute of Standards and Technology (NIST, Gaithersburg, MD, USA) and IAEA 140-TM (Fucus sp.) from International Atomic Energy Agency (IAEA, Viena, Austria). Samples of different cereals were purchased at the local market in Valencia (Spain). Rice, rice semolina, wheat semolina, wheat bran and rye flakes were ground in a domestic mill Taurus (Leida, Spain) and the powdered samples were stored in polyethylene bottles inside a dessicator until analysis together with wheat semolina and wheat corn that were stored directly.

\section{Dry ashing mineralization for total element determination}

Approximately $1 \mathrm{~g}$ of sample was accurately weighed and mixed with $2.5 \mathrm{~mL}$ of an ashing aid suspension containing $20 \% \mathrm{~m} / \mathrm{v} \mathrm{Mg}\left(\mathrm{NO}_{3}\right)_{2} \cdot 6 \mathrm{H}_{2} \mathrm{O}$ plus $2 \% \mathrm{~m} / \mathrm{v} \mathrm{MgO}$, and $5 \mathrm{~mL}$ of $50 \% \mathrm{v} / \mathrm{v} \mathrm{HNO}_{3}$. The mixture was evaporated to dryness in a sand bath and mineralized in a muffle furnace at $450{ }^{\circ} \mathrm{C}$ with a gradual increase in temperature. ${ }^{24}$ The white ashes were wetted with $1 \mathrm{~mL}$ water and dissolved with $9 \mathrm{~mL}$ of $10 \% \mathrm{v} / \mathrm{v} \mathrm{HCl}$. For Sb determination, $3 \mathrm{~mL}$ of this solution were transferred to a $50 \mathrm{~mL}$ polyethylene tube, as well as $8.75 \mathrm{~mL}$ of concentrated $\mathrm{HCl}$ and $600 \mu \mathrm{L}$ 
of the $50 \% \mathrm{~m} / \mathrm{v}$ KI plus $10 \% \mathrm{~m} / \mathrm{v}$ ascorbic acid reducing solution. The final volume was made up to $30 \mathrm{~mL}$ with ultrapure water. For Te determination, $5 \mathrm{~mL}$ of the ashed sample solution were transferred to a $50 \mathrm{~mL}$ polyethylene tube, as well as $16.7 \mathrm{~mL}$ of concentrated $\mathrm{HCl}$ and $0.5 \mathrm{~g}$ of $\mathrm{KBr}$. Then, this solution was diluted to $50 \mathrm{~mL}$ with ultrapure water. The final solution was warmed during $30 \mathrm{~min}$ at $75 \pm 5^{\circ} \mathrm{C}$. Recovery studies previously made evidenced that for a spiked concentration of $\mathrm{Sb}$ and $\mathrm{Te}$ at $100 \mathrm{ng} \mathrm{g}^{-1}$ level, the aforementioned elements were recovered at 91 and $98 \%$ respectively from vegetable, cereal and pulses samples. ${ }^{24}$

\section{Ultrasound-assisted extraction for inorganic trace element determination}

Approximately $1 \mathrm{~g}$ of sample was accurately weighed inside a $50 \mathrm{~mL}$ polyethylene tube, and a volume of $10 \mathrm{~mL}$ of $1 \mathrm{~mol} \mathrm{~L}^{-1} \mathrm{H}_{2} \mathrm{SO}_{4}$ was added to the tube. The slurry was sonicated for $10 \mathrm{~min}$, and the sulphuric extract separated by centrifugation at $3500 \mathrm{rpm}$ for $10 \mathrm{~min}$. The solid residue was washed with $10 \mathrm{~mL}$ of $0.1 \% \mathrm{~m} / \mathrm{v}$ ethylenediaminetetraacetic acid (EDTA); this suspension was centrifuged for additional $10 \mathrm{~min}$, and the supernatant was mixed with the previous extract. Two aliquots were taken from the final extract, for $\mathrm{Sb}(\mathrm{III})$ and $\mathrm{Sb}(\mathrm{V})$ determination. One of the aliquots was prepared in a medium containing $1 \% \mathrm{~m} / \mathrm{v} \mathrm{KI}$ and $0.2 \% \mathrm{~m} / \mathrm{v}$ ascorbic acid and was left to react for $30 \mathrm{~min}$ for $\mathrm{Sb}(\mathrm{V})$ reduction; the another one was analyzed directly by HG AFS without pre-reduction; the final $\mathrm{HCl}$ medium in both cases, was adjusted to $3.5 \mathrm{~mol} \mathrm{~L}^{-1}$. For Te speciation, two aliquots were taken also from the sonicated solutions. One aliquot was prepared in a medium containing $4 \mathrm{~mol} \mathrm{~L}^{-1} \mathrm{HCl}$ plus $1 \% \mathrm{~m} / \mathrm{v} \mathrm{KBr}$ and the solution was warmed for $30 \mathrm{~min}$ at $75 \pm 5^{\circ} \mathrm{C}$ before HG AFS determination of Te(IV) and Te(VI). The other one was analyzed directly after acidification for the determination of $\mathrm{Te}(\mathrm{IV})$.

\section{Results and Discussion}

\section{Selection of the extraction conditions for inorganic antimony and tellurium determination}

The selection of the extracting agents was based on previous works made for the determination of trace elements in garlic, ${ }^{15}$ and the speciation of As in cereals, ${ }^{25}$ thus, the following extractants were investigated: $1 \mathrm{~mol} \mathrm{~L}^{-1}$ $\mathrm{HNO}_{3}, 1 \mathrm{~mol} \mathrm{~L}^{-1} \mathrm{H}_{3} \mathrm{PO}_{4}, 1 \mathrm{~mol} \mathrm{~L}^{-1} \mathrm{H}_{2} \mathrm{SO}_{4}, 6 \mathrm{~mol} \mathrm{~L}^{-1} \mathrm{HCl}$ and aqua regia. Extractions carried out with $6 \mathrm{~mol} \mathrm{~L}^{-1} \mathrm{HCl}$, $1 \mathrm{~mol} \mathrm{~L}^{-1} \mathrm{HNO}_{3}$ and $1 \mathrm{~mol} \mathrm{~L}^{-1} \mathrm{H}_{3} \mathrm{PO}_{4}$ led to erroneous results of inorganic antimony $[\mathrm{Sb}(\mathrm{III})+\mathrm{Sb}(\mathrm{V})]$ and tellurium $[\mathrm{Te}(\mathrm{IV})+\mathrm{Te}(\mathrm{VI})]$ because the levels obtained were higher than the total concentration of these elements in the considered samples. These results may be explained by interference effects in the hydride generation process. Therefore, the aforementioned extractants were not taken into account for further studies. Sulphuric acid $\left(1 \mathrm{~mol} \mathrm{~L}^{-1}\right)$ and aqua regia resulted the most efficient extractants of Te and Sb from cereals. However, for Sb, a separate extraction was carried out with aqua regia for the same sample of rice, giving different concentrations of $\mathrm{Sb}(\mathrm{III})$ and $\mathrm{Sb}(\mathrm{V})$, despite that the total content of inorganic $\mathrm{Sb}$ was quite reproducible. Additionally, the total content of Te species extracted was around $85 \%$ for the total content of $\mathrm{Te}$, and data found for $\mathrm{Te}(\mathrm{IV})$ were quite higher than those expected (see Table 2). Consequently, $1 \mathrm{~mol} \mathrm{~L}^{-1} \mathrm{H}_{2} \mathrm{SO}_{4}$ was selected as the best extracting agent for speciation of $\mathrm{Sb}$ and $\mathrm{Te}$ in cereals. Results show a reproducible distribution of $\mathrm{Sb}$ and $\mathrm{Te}$ species in the studied sample, being $\mathrm{Sb}(\mathrm{V})$ and $\mathrm{Te}(\mathrm{VI})$ the main chemical forms in this sample.

Strategy for the speciation analysis of $S b(I I I), S b(V), T e(I V)$ and $T e(V I)$

The speciation strategy was based on previous experience in non-chromatographic speciation by HG AFS which evidenced that $\mathrm{Sb}(\mathrm{V})$ reacts with $\mathrm{NaBH}_{4}$ forming

Table 2. Selection of the best extractant for the $\mathrm{Sb}$ and Te determination in a rice sample

\begin{tabular}{|c|c|c|c|c|c|c|}
\hline Extractant & $\begin{array}{l}\mathrm{Sb}(\mathrm{III}) \\
\left(\mathrm{ng} \mathrm{g}^{-1}\right)\end{array}$ & $\begin{array}{l}\mathrm{Sb}(\mathrm{V}) \\
\left(\mathrm{ng} \mathrm{g}^{-1}\right)\end{array}$ & $\begin{array}{c}\mathrm{Sb}(\mathrm{III})+\mathrm{Sb}(\mathrm{V}) \\
\left(\mathrm{ng} \mathrm{g}^{-1}\right)\end{array}$ & $\begin{array}{l}\mathrm{Te}(\mathrm{IV}) \\
\left(\mathrm{ng} \mathrm{g}^{-1}\right)\end{array}$ & $\begin{array}{l}\mathrm{Te}(\mathrm{VI}) \\
\left(\mathrm{ng} \mathrm{g}^{-1}\right)\end{array}$ & $\begin{array}{c}\mathrm{Te}(\mathrm{IV})+\mathrm{Te}(\mathrm{VI}) \\
\left(\mathrm{ng} \mathrm{g}^{-1}\right)\end{array}$ \\
\hline \multirow[t]{3}{*}{$\mathrm{H}_{2} \mathrm{SO}_{4} 1 \mathrm{~mol} \mathrm{~L}^{-1}$} & 0.15 & 0.47 & 0.63 & 0.28 & 0.87 & 1.15 \\
\hline & 0.15 & 0.45 & 0.60 & 0.26 & 0.75 & 1.01 \\
\hline & 0.16 & 0.49 & 0.64 & 0.27 & 0.73 & 1.00 \\
\hline \multirow[t]{3}{*}{ aqua regia } & 0.13 & 0.36 & 0.50 & 0.58 & 0.19 & 0.77 \\
\hline & 0.35 & 0.16 & 0.52 & 0.51 & 0.18 & 0.69 \\
\hline & 0.26 & 0.25 & 0.51 & 0.53 & 0.36 & 0.90 \\
\hline
\end{tabular}

Total Sb: $0.65 \pm 0.03 \mathrm{ng} \mathrm{g}^{-1}$; Total Te: $0.93 \pm 0.04 \mathrm{ng} \mathrm{g}^{-1}$. 
stibine with a reaction kinetics slower than that of $\mathrm{Sb}(\mathrm{III}){ }^{23}$ So, the AFS signals produced by the pentavalent species of $\mathrm{Sb}$ depend on hydride generation conditions. In order to determine the total $\mathrm{Sb}$ content a pre-reduction is thus required to reduce quantitatively $\mathrm{Sb}(\mathrm{V})$ to $\mathrm{Sb}(\mathrm{III})$. Based on the different AFS sensitivity obtained from $\mathrm{Sb}(\mathrm{V})$ with and without pre-reduction, it could be possible to determine $\mathrm{Sb}$ (III) and $\mathrm{Sb}(\mathrm{V})$ concentrations on the same sample based on two independent measurements, one without a previous reduction and another after a quantitative transformation of $\mathrm{Sb}$ to $\mathrm{Sb}(\mathrm{III})$, and to establish a system of two equations with two unknowns related to the oxidation states of $\mathrm{Sb} .{ }^{15} \mathrm{On}$ the other hand, $\mathrm{Te}(\mathrm{VI})$ does not react with $\mathrm{NaBH}_{4}$ to form the corresponding hydrides, being necessary to reduce it to the (IV) oxidation state with $\mathrm{KBr}$ or boiling using 2-6 mol L-1 $\mathrm{HCl}$ before HG AFS measurements. ${ }^{26}$ Therefore, speciation of Te(IV), Te(VI) can be easily carried out by HG AFS using a two step analysis. Samples must be analysed without pre-reduction, in order to determine Te(IV) concentrations; then, the sample must be treated with $\mathrm{KBr}$ in acidic medium at $75 \pm 5{ }^{\circ} \mathrm{C}$ for $30 \mathrm{~min}$ in order to achieve a quantitative reduction of $\mathrm{Te}(\mathrm{VI})$ to $\mathrm{Te}(\mathrm{IV})$ present in the sample. The analysis of this last solution gives the total concentration of $\mathrm{Te}$ (IV) and Te(VI), and can be calculated by the difference between the two analysis performed. ${ }^{22}$

\section{Analytical figures of merit}

The main analytical parameters of the developed procedure, such as sensitivity, limit of detection (LOD) and precision are summarized in Table 3, together with the slope of typical regression equations obtained before and after $\mathrm{KI}$ or $\mathrm{KBr}$ reduction. The $\mathrm{LOD}$ values were calculated by dividing three times the standard deviation of the fluorescence signal of 10 reagent blanks by the slope of the calibration curve, in the best experimental conditions, for each $\mathrm{Sb}$ and Te species. The LOD was also established for dried samples, taking into account the sample mass and dilution factor involved in the proposed method. The precision expressed as relative standard deviation (RSD\%) for 10 replicate analysis of a sample is also reported. As it can be seen, concentrations from 0.1 to $0.5 \mathrm{ng} \mathrm{g}^{-1}$ of $\mathrm{Sb}$ and Te species can be detected and concentrations of few $\mathrm{ng} \mathrm{g}^{-1}$ can be determined with relative standard deviations from 5.4 to $9.2 \%$.

\section{Accuracy studies}

To evaluate the accuracy of the inorganic species determination in cereal samples, a series of recovery studies on a rice sample spiked with different concentrations of
Table 3. Analytical figures of merit obtained for non-chromatographic speciation of inorganic $\mathrm{Sb}$ and Te in cereal samples through HG AFS

\begin{tabular}{|c|c|c|c|}
\hline Element & $\begin{array}{l}\text { LOD } \\
\left(\mathrm{ng} \mathrm{g}^{-1}\right)\end{array}$ & $\begin{array}{r}\mathrm{RSD} \\
(\%)\end{array}$ & Regression equation \\
\hline $\mathrm{Sb}(\mathrm{III})_{\text {red }}$ & \multirow[b]{2}{*}{0.1} & \multirow[b]{2}{*}{7.6} & $\begin{array}{c}y=1280.9 x+8.8 \\
R^{2}=0.9974\end{array}$ \\
\hline $\mathrm{Sb}(\mathrm{III})$ & & & $\begin{array}{c}y=1159.8 x+10.7 \\
R^{2}=0.9991\end{array}$ \\
\hline $\mathrm{Sb}(\mathrm{V})_{\mathrm{red}}$ & \multirow{2}{*}{0.2} & \multirow{2}{*}{5.4} & $\begin{array}{c}y=1167.8 x+4.6 \\
R^{2}=0.9995\end{array}$ \\
\hline $\mathrm{Sb}(\mathrm{V})$ & & & $\begin{array}{c}y=544.9 x+12.4 \\
R^{2}=0.9961\end{array}$ \\
\hline $\mathrm{Te}(\mathrm{IV})$ & 0.2 & 9.2 & $\begin{array}{c}y=315.8 x+4.2 \\
R^{2}=0.9922\end{array}$ \\
\hline $\mathrm{Te}(\mathrm{VI})_{\text {red }}$ & 0.5 & 8.2 & $\begin{array}{c}y=426.6 x+11.8 \\
R^{2}=0.9991\end{array}$ \\
\hline
\end{tabular}

$\mathrm{Sb}$ (III), $\mathrm{Sb}(\mathrm{V}), \mathrm{Te}(\mathrm{IV})$ and $\mathrm{Te}(\mathrm{VI})$ were made to verify the lack of interconversion of original species during the extraction and measurement steps. The sample was spiked with 10, 20 and $40 \mathrm{ng} \mathrm{g}^{-1}$ of each specie before the extraction process. The recovery values were always higher than 95\% for all the species considered at the spiked levels (see Table 4). These good recovery values evidence the stability of each species during the extraction process. In relation to organic species of $\mathrm{Sb}$ and $\mathrm{Te}$, it was not possible to evaluate the possible presence of organic species because organic standards are not commercially available. However, the good correlation between the sum of inorganic species and the total concentration values seems to indicate the absence of organic species of the aforementioned elements in cereal samples.

It was also determined the concentration of $\mathrm{Sb}$ (III), $\mathrm{Sb}(\mathrm{V}), \mathrm{Te}(\mathrm{IV})$ and $\mathrm{Te}(\mathrm{VI})$ in two certified reference materials, NIST 1573a (tomato leaves) and IAEA 140-TM (Fucus sp). Results obtained (see Table 5) evidence that the sum of the analyzed species agree well with the total $\mathrm{Sb}$ certified value and in the case of Te, there is not available certified sample.

\section{Analysis of commercial cereal samples}

Samples of cereals, obtained from the local market of Valencia were analyzed by the proposed procedure and results found for $\mathrm{Sb}$ and $\mathrm{Te}$ species are summarized in Tables 6 and 7, together with data found for total Sb and Te determination based on dry-ashing mineralization and HG AFS. The $t$-test demonstrated that there are no significant differences between the results found for total $\mathrm{Sb}$ and total Te and those obtained from the sum of the species determined by the proposed method $\left(-0.49<\mathrm{t}_{\text {critical }}=2.57\right)$. 
Table 4. Recovery percentages of inorganic Sb and Te species in cereal samples by HG AFS in three different addition levels, all results were the average and standard deviation of $\mathrm{n}=3$ determinations

\begin{tabular}{lccccccc}
\hline $\begin{array}{l}\mathrm{Sb}(\mathrm{III}) \\
\left(\mathrm{ng} \mathrm{g}^{-1}\right)\end{array}$ & $\begin{array}{c}\text { Recovery } \\
(\%)\end{array}$ & $\begin{array}{c}\mathrm{Sb}(\mathrm{V}) \\
\left(\mathrm{ng} \mathrm{g}^{-1}\right)\end{array}$ & $\begin{array}{c}\text { Recovery } \\
(\%)\end{array}$ & $\begin{array}{c}\mathrm{Te}(\mathrm{IV}) \\
\left(\mathrm{ng} \mathrm{g}^{-1}\right)\end{array}$ & $\begin{array}{c}\text { Recovery } \\
(\%)\end{array}$ & $\begin{array}{c}\mathrm{Te}(\mathrm{VI}) \\
\left(\mathrm{ng} \mathrm{g}^{-1}\right)\end{array}$ & $\begin{array}{c}\text { Recovery } \\
(\%)\end{array}$ \\
\hline 10 & $99.4 \pm 1.5$ & 10 & $95.4 \pm 1.4$ & 10 & $99 \pm 3$ & 10 & $98.4 \pm 0.9$ \\
20 & $97 \pm 2$ & 20 & $99 \pm 3$ & 20 & $94.6 \pm 1.4$ & 20 & $98 \pm 2$ \\
40 & $101 \pm 4$ & 40 & $100.0 \pm 0.7$ & 40 & $98.9 \pm 1.1$ & 40 & $100.0 \pm 0.8$ \\
\hline
\end{tabular}

Table 5. Antimony and Te species found in NIST 1573a (tomato leaves) and IAEA 140-TM (Fucus sp)

\begin{tabular}{lcccccc}
\hline CRM & $\begin{array}{c}\mathrm{Sb}(\mathrm{III}) \\
\left(\mathrm{ng} \mathrm{g}^{-1}\right)\end{array}$ & $\begin{array}{c}\mathrm{Sb}(\mathrm{V}) \\
\left(\mathrm{ng} \mathrm{g}^{-1}\right)\end{array}$ & $\begin{array}{c}\mathrm{Sb}(\mathrm{III})+\mathrm{Sb}(\mathrm{V}) \\
\left(\mathrm{ng} \mathrm{g}^{-1}\right)\end{array}$ & $\begin{array}{c}\mathrm{Te}(\mathrm{IV}) \\
\left(\mathrm{ng} \mathrm{g}^{-1}\right)\end{array}$ & $\begin{array}{c}\mathrm{Te}(\mathrm{VI}) \\
\left(\mathrm{ng} \mathrm{g}^{-1}\right)\end{array}$ & $\begin{array}{c}\mathrm{Te}(\mathrm{IV})+\mathrm{Te}(\mathrm{VI}) \\
\left(\mathrm{ng} \mathrm{g}^{-1}\right)\end{array}$ \\
\hline NIST 1573 & $14.4 \pm 1.1$ & $50.8 \pm 1.7$ & $64.8 \pm 1.9$ & $31 \pm 2$ & $11 \pm 2$ & $41 \pm 3$ \\
IAEA 140-TM & $50.0 \pm 0.3$ & $52.8 \pm 0.4$ & $103.5 \pm 0.8$ & $45.0 \pm 0.15$ & $20 \pm 3$ & $65 \pm 3$ \\
\hline
\end{tabular}

Total certified value for NIST 1573a: $\mathrm{Sb}=0.063 \pm 0.006 \mu \mathrm{g} \mathrm{g}^{-1}$; Recommended value for IAEA 140-TM: $\mathrm{Sb}=0.103 \mu \mathrm{g} \mathrm{g}^{-1}$.

Table 6. Determination of $\mathrm{Sb}(\mathrm{III})$ and $\mathrm{Sb}(\mathrm{V})$ in cereal samples by HG AFS, expressed as mean \pm standard deviation for $\mathrm{n}=3$

\begin{tabular}{|c|c|c|c|c|}
\hline Sample & $\begin{array}{l}\mathrm{Sb}(\mathrm{III}) \\
\left(\mathrm{ng} \mathrm{g}^{-1}\right)\end{array}$ & $\begin{array}{l}\mathrm{Sb}(\mathrm{V}) \\
\left(\mathrm{ng} \mathrm{g}^{-1}\right)\end{array}$ & $\begin{array}{c}\mathrm{Sb}(\mathrm{IIII})+\mathrm{Sb}(\mathrm{V}) \\
\left(\mathrm{ng} \mathrm{g}^{-1}\right)\end{array}$ & $\begin{array}{l}\text { Total Sb } \\
\left(\text { ng g }^{-1}\right)\end{array}$ \\
\hline Rice & $0.15 \pm 0.01$ & $0.47 \pm 0.02$ & $0.6 \pm 0.2$ & $0.65 \pm 0.03$ \\
\hline Wheat semolina & $<$ LOD & $<$ LOD & - & $<$ LOD \\
\hline Wheat flour & $0.19 \pm 0.03$ & $0.22 \pm 0.09$ & $0.39 \pm 0.03$ & $0.34 \pm 0.05$ \\
\hline Corn flour & $0.19 \pm 0.07$ & $0.33 \pm 0.10$ & $0.52 \pm 0.09$ & $0.5 \pm 0.1$ \\
\hline Rice semolina & $0.17 \pm 0.11$ & $0.30 \pm 0.09$ & $0.38 \pm 0.08$ & $0.42 \pm 0.06$ \\
\hline Wheat bran & $1.6 \pm 0.4$ & $1.2 \pm 0.3$ & $2.9 \pm 0.5$ & $2.9 \pm 0.3$ \\
\hline Rye flakes & $1.5 \pm 0.3$ & $1.4 \pm 0.3$ & $2.9 \pm 0.5$ & $2.9 \pm 0.1$ \\
\hline Rye flour & $<$ LOD & $<$ LOD & - & $<$ LOD \\
\hline
\end{tabular}

${ }^{\mathrm{a} L O D}$ for total $\mathrm{Sb}: 0.2 \mathrm{ng} \mathrm{g}^{-1}$.

Table 7. Determination of Te(IV) and Te(VI) in cereal samples by HG AFS, expressed as mean \pm standard deviation for $\mathrm{n}=3$

\begin{tabular}{|c|c|c|c|c|}
\hline Sample & $\begin{array}{l}\mathrm{Te}(\mathrm{IV}) \\
\left(\mathrm{ng} \mathrm{g}^{-1}\right)\end{array}$ & $\begin{array}{l}\mathrm{Te}(\mathrm{VI}) \\
\left(\mathrm{ng} \mathrm{g}^{-1}\right) \\
\end{array}$ & $\begin{array}{c}\mathrm{Te}(\mathrm{IV})+\mathrm{Te}(\mathrm{VI}) \\
\left(\mathrm{ng} \mathrm{g}^{-1}\right)\end{array}$ & $\begin{array}{l}\text { Total Tea } \\
\left(\mathrm{ng} \mathrm{g}^{-1}\right) \\
\end{array}$ \\
\hline Rice & $0.32 \pm 0.07$ & $0.70 \pm 0.10$ & $1.00 \pm 0.14$ & $0.93 \pm 0.04$ \\
\hline Wheat semolina & $<$ LOD & $<\mathrm{LOD}$ & - & $<$ LOD \\
\hline Wheat flour & $<$ LOD & $<$ LOD & - & $<$ LOD \\
\hline Wheat corn & $<\mathrm{LOD}$ & $<\mathrm{LOD}$ & - & $<\mathrm{LOD}$ \\
\hline Rice semolina & $0.42 \pm 0.06$ & $0.97 \pm 0.11$ & $1.38 \pm 0.16$ & $1.41 \pm 0.08$ \\
\hline Wheat bran & $4.2 \pm 0.2$ & $8.5 \pm 0.3$ & $12.7 \pm 0.4$ & $12.7 \pm 0.5$ \\
\hline Rye flakes & $0.59 \pm 0.08$ & $0.72 \pm 0.09$ & $1.3 \pm 0.2$ & $1.3 \pm 0.2$ \\
\hline Rye flour & $6.9 \pm 0.3$ & $12.9 \pm 0.2$ & $19.8 \pm 0.3$ & $20 \pm 2$ \\
\hline
\end{tabular}

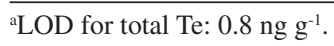

From the different type of samples analyzed it can be concluded that $\mathrm{Te}(\mathrm{VI})$ is the main specie of $\mathrm{Te}$ in raw cereals and cereal based products. On considering $\mathrm{Sb}$ species it seems that $\mathrm{Sb}(\mathrm{V})$ is predominant in raw cereals being modified the relationship between $\mathrm{Sb}(\mathrm{V})$ and $\mathrm{Sb}(\mathrm{III})$ from processed cereal based products. However, additional studies would be required to obtain a clear conclusion of this point. 


\section{Conclusions}

The non-chromatographic strategy developed for $\mathrm{Sb}$ (III), $\mathrm{Sb}(\mathrm{V}), \mathrm{Te}(\mathrm{IV})$ and $\mathrm{Te}(\mathrm{VI})$ determination in cereals and cereal based products by HG AFS offers a simple and sensitive alternative to hyphenated techniques for speciation analysis. The speciation analysis of $\mathrm{Sb}$ and $\mathrm{Te}$ in cereal samples based on the sonication of samples for $10 \mathrm{~min}$ with $1 \mathrm{~mol} \mathrm{~L}^{-1} \mathrm{H}_{2} \mathrm{SO}_{4}$ at room temperature, followed by a washing step with EDTA provides quantitative recoveries of both considered elements and does not modify the original $\mathrm{Sb}$ and Te species present in cereals. The levels of $\mathrm{Sb}(\mathrm{III}), \mathrm{Sb}(\mathrm{V}), \mathrm{Te}(\mathrm{IV})$ and $\mathrm{Te}(\mathrm{VI})$ found, evidenced that the developed procedure is suitable to obtain quantitative data for cereal samples and that is a guarantee of the absence of risks in the consumption of the considered samples.

\section{Acknowledgments}

The authors gratefully acknowledge to the Ministerio de Educación y Ciencia Project AGL2007-64567 for the financial support.

\section{References}

1. Fowler, B. A.; Goering, P. L. In Metals and their Compounds in the Environment: Occurrence, Analysis and Biological Relevance; Merian, E., ed.; VCH Verlagsgesellschaft: Weinhein, 1991, ch. 2.

2. Cal-Prieto, M. J.; Carlosena, A.; Andrade, J. M.; Martínez, M. L.; Muniategui, S.; López-Mahía, P.; Prada, D.; Water, Air, Soil Pollut. 2001, 129, 333.

3. Amereih, S.; Meisel, T.; Scholger, R.; Wegscheider, W.; J. Environ. Monit. 2005, 7, 1200 .

4. Hammel, W.; Debus, R.; Steubing, L.; Chemosphere 2000, 41, 1791.

5. Frézard, F.; Demicheli, C.; Ribeiro, R. R.; Molecules 2009, 14, 2317.

6. Sharma, P.; Perez, D.; Cabrera, A.; Rosasi, N.; Arias, J. L.; Acta Pharmacol. Sin. 2008, 29, 881 .
7. Sadeh, T. In The Chemistry of Organic Selenium and Tellurium Compounds; Patai, S., ed.; Wiley: New York, 1987, ch. 11, p. 367.

8. Karlson, U.; Frankenberger, W. T.; Metal Ions in Biological Systems, Marcel Dekker: New York, 1993.

9. Centre for Food Safety, Hong Kong, China, http://www.cfs.gov. hk, accessed in December 2009.

10. Emsley, J.; The Elements of Murder, Oxford University Press: Oxford, UK, 2005.

11. Locatelli, C.; Torsi, G.; Microchem. J. 2003, 75, 233.

12. Locatelli, C; Anal. Bioanal. Chem. 2005, 381, 1073.

13. Locatelli, C.; J. Sci. Food Agric. 2007, 87, 305.

14. Miravet, R.; Hernandez-Nataren, E.; Sahuquillo, A.; Rubio, R.; López-Sánchez, J. F.; TrAC, Trends Anal. Chem. 2010, 29, 28.

15. Matos-Reyes, M. N.; Cervera, M. L.; De la Guardia, M.; Anal. Bioanal. Chem. 2009, 394, 1557.

16. Sousa-Ferreira, H.; Costa-Ferreira, S. L.; Cervera, M. L.; De la Guardia, M.; Spectrochim. Acta, Part B 2009, 64, 597.

17. Cava-Montesinos, P.; De la Guardia, A.; Teutsch, C.; Cervera, M. L.; De la Guardia, M.; Anal. Chim. Acta 2003, 493, 195.

18. Morita, Y.; Kobayashi, T.; Kuroiwa, T; Narukawa, T.; Talanta 2007, 73, 81

19. Kuo, C. Y.; Jiang, S. J.; J. Chromatogr., A 2008, 1181, 60.

20. Narukawa, T.; J. Anal. At. Spectrom. 1999, 14, 75.

21. Yu, C.; Cai, Q. T.; Guo, Z. X.; Yang, Z.; Khoo, S. B.; Anal. Bioanal. Chem. 2003, 376, 236.

22. Cava-Montesinos, P.; De la Guardia, A.; Teustch, C.; Cervera, M. L.; De la Guardia, M.; J. Anal. At. Spectrom. 2004, 19, 696.

23. Gonzalvez, A.; Armenta, S.; Cervera, M. L.; De la Guardia, M.; TrAC, Trends Anal. Chem. 2010, 29, 260.

24. Matos-Reyes, M. N.; Cervera, M. L.; Campos, R. C.; De la Guardia, M.; Food Chem. 2010, 122, 188.

25. Matos-Reyes, M. N.; Cervera, M. L.; Campos, R. C.; De la Guardia, M.; Talanta 2008, 75, 811.

26. Nakahara, T.; Bunseki Kagaku 1997, 46, 513.

Submitted: May 21, 2010 Published online: September 8, 2010 